\title{
Video Article \\ Feeder-Free Adaptation, Culture and Passaging of Human IPS Cells using Complete KnockOut Serum Replacement Feeder-Free Medium
}

\author{
Kate Wagner ${ }^{1}$, David Welch ${ }^{1}$ \\ ${ }^{1}$ GIBCO, Life Technologies \\ URL: https://www.jove.com/video/2236 \\ DOI: doi:10.3791/2236
}

Keywords: Cellular Biology, Issue 41, iPS, pluripotent, stem cells, cell culture, medium, media, feeder-free, Geltrex, human

Date Published: $7 / 15 / 2010$

Citation: Wagner, K., Welch, D. Feeder-Free Adaptation, Culture and Passaging of Human IPS Cells using Complete KnockOut Serum Replacement Feeder-Free Medium. J. Vis. Exp. (41), e2236, doi:10.3791/2236 (2010).

\section{Abstract}

The discovery in 2006 that human and mouse fibroblasts could be reprogrammed to generate iPS cells ${ }^{1-3}$ with qualities remarkably similar to embryonic stem cells has created a valuable new source of pluripotent cells for drug discovery, cell therapy, and basic research.

GIBCO media and reagents have been at the forefront of pluripotent stem cell research for years. Knockout DMEM supplemented with Knockout Serum Replacement is the media of choice for embryonic stem cell growth and now iPS cell culture ${ }^{3-9}$. This gold standard media system can now be used for feeder-free culture with the addition of Knockout SR Growth Factor Cocktail.

Traditional human ES and iPS cell culture methods require the use of mouse or human fibroblast feeder layers, or feeder-conditioned medium. These culture methods are labor-intensive, hard to scale and it is difficult to maintain hiPS cells undifferentiated due to the undefined conditions. Invitrogen has developed Knockout SR Growth Factor Cocktail to allow you to easily transition your hiPS cell cultures to feeder-free while still maintaining your use of Knockout SR.

\section{Video Link}

The video component of this article can be found at https://www.jove.com/video/2236/

\section{Protocol}

Note: To maintain sterile culture conditions, all of the procedures in this protocol are carried out using sterile laboratory practices and conducted under a laminar flow hood.

Prior to starting, ensure that any media is equilibrated to $37^{\circ} \mathrm{C}$ and appropriately gassed.

\section{Preparing Geltrex-coated Culture Dishes}

Note: see appendix for the use of CELLstart coated culture dishes

1. Thaw one tube of Geltrex $(1 \mathrm{~mL})$ slowly at $2-8^{\circ} \mathrm{C}$ and dilute $1: 100$ it in $99 \mathrm{~mL}$ of Knockout D-MEM/F-12. Mix the solution gently. Note: Some iPS cell lines may require a different Geltrex dilution for optimal growth. See appendix for alternative dilutions.

2. Cover the whole surface of each culture dish with the Geltrex solution ( $1 \mathrm{~mL}$ for a $35-\mathrm{mm}$ dish, $1.5 \mathrm{~mL}$ for a $60-\mathrm{mm}$ dish).

3. Seal each dish with Parafilm to prevent drying and incubate the dishes for 1 hour at $37^{\circ} \mathrm{C}$.

Note: At this point you may store the Geltrex-coated culture dishes at $4^{\circ} \mathrm{C}$ for up to 1 month. Seal each dish with Parafilm to prevent the Geltrex from drying out.

4. Prior to using, transfer the Geltrex-coated dishes to a laminar flow hood and allow them to equilibrate to room temperature (about 1 hour).

\section{Preparing Complete KnockOut SR Feeder-Free Medium}

1. To prepare $1 \mathrm{~mL}$ of $10 \mu \mathrm{g} / \mathrm{mL}$ Basic FGF solution, aseptically mix the components listed below. Aliquot the solution and store at $-20^{\circ} \mathrm{C}$ for up to 6 months.

\begin{tabular}{|l|l|}
\hline Basic FGF & $10 \mu \mathrm{g}$ \\
\hline D-PBS & $990 \mu \mathrm{L}$ \\
\hline $10 \%$ BSA & $10 \mu \mathrm{L}$ \\
\hline
\end{tabular}

Note: BSA can be substituted with HSA or Knockout SR at the same concentration.

2. To prepare $50 \mathrm{~mL}$ of $2 \mathrm{mg} / \mathrm{mL}$ Dispase solution, aseptically mix the components listed below. Filter sterilize the solution and store at $4^{\circ} \mathrm{C}$ for up to 2 weeks. 


\begin{tabular}{|l|l|}
\hline Dispase & $100 \mathrm{mg}$ \\
\hline D-PBS & $50 \mathrm{~mL}$ \\
\hline
\end{tabular}

3. To prepare $100 \mathrm{~mL}$ of complete KnockOut SR Feeder-Free (KSR-FF) medium aseptically combine the components listed in the table below.

\begin{tabular}{|l|c|c|c|}
\hline Component & Stock Concentration & Final Concentration & Volume \\
\hline $\begin{array}{l}\text { Knockout DMEM/F12 (Cat. } \\
\text { no. 12660-012) }\end{array}$ & - & $1 \mathrm{X}$ & $76.8 \mathrm{~mL}$ \\
\hline $\begin{array}{l}\text { GlutaMAX-I (Cat. No. } \\
\text { 35050-061) }\end{array}$ & $200 \mathrm{mM}$ & $2 \mathrm{mM}$ & $1 \mathrm{~mL}$ \\
\hline $\begin{array}{l}\text { KnockOut SR (Cat. no. } \\
\text { 10828-028) }\end{array}$ & - & $20 \%$ & $20 \mathrm{~mL}$ \\
\hline $\begin{array}{l}\text { KnockOut SR-GFC (Cat. } \\
\text { no. A10580-01) }\end{array}$ & $50 \mathrm{X}$ & $1 \mathrm{X}$ & $2 \mathrm{~mL}$ \\
\hline bFGF (Cat. no. PHG0024) & $10 \mu \mathrm{g} / \mathrm{mL}$ & $20 \mathrm{ng} / \mathrm{mL}$ & $200 \mu \mathrm{L}$ \\
\hline
\end{tabular}

You may store the KSR-FF medium at $2-8^{\circ} \mathrm{C}$ for up to one week.

4. Just before pre-equilibrating the complete medium to temperature and gases, aseptically add the required volume of 2 mercaptoethanol ( $55 \mathrm{mM}$ stock concentration) for a $0.1 \mathrm{mM}$ final concentration. For example, to prepare $100 \mathrm{~mL}$ of KSR-FF medium add $182 \mu \mathrm{L}$ of $55 \mathrm{mM} 2-$ mercaptoethanol (1:550 dilution) Alternatively, the 2-mercaptoethanol may be added to the $1 \mathrm{X}$ completed medium and stored at $2-8^{\circ} \mathrm{C}$ for up to one week.

\section{Adapting iPSCs to KSR-FF Medium}

1. Prior to starting, pre-equilibrate your Geltrex coated dishes to room temperature in the hood.

2. Culture the iPSCs on MEF feeder cells until they are $70-80 \%$ confluent. Please refer to the GIBCO Mouse Embryonic Fibroblast handbook for MEF-based culture protocols.

3. Pre-warm the required volume of Dispase in a $37^{\circ} \mathrm{C}$ water bath. Refer to Table 1 below for details on the volumes required.

4. Pre-equilibrate the required volume of $\mathrm{KSR}-\mathrm{FF}$ in a $37^{\circ} \mathrm{C}$ water bath for $15 \mathrm{~min}$. Refer to Table 1 below for details on the volumes required.

5. Aspirate the medium from the culture dishes, and add an appropriate amount of Dispase solution. Incubate the dishes at $37^{\circ} \mathrm{C}$ for $3-5$ minutes.

6. Aspirate the Dispase solution from each culture vessel and wash off the MEF feeder cells gently with D-PBS (2 to 3 times).

7. Add an appropriate amount of complete KnockOut SR medium to each culture vessel. Use a cell scraper or a $5 \mathrm{~mL}$ pipette to gently scrape the cells off the surface of culture vessel. Note: see appendix for alternative adaptation protocols for hard to adapt iPS cell lines,

8. Collect the cell suspension from each culture dish into separate $15 \mathrm{~mL}$ conical tubes. Rinse each culture vessel with an appropriate amount of complete KnockOut SR medium, and add the D-PBS rinse medium into the $15 \mathrm{~mL}$ conical tubes containing the cell suspension. Be cautious not to break the cell clumps into single cells

9. Centrifuge the $15 \mathrm{~mL}$ conical tubes at $200 \times g$ for 5 minutes to pellet the iPSCs.

10. Aspirate the supernatant from the iPSC pellet. Resuspend the pellet in an appropriate amount of KSR-FF medium according to the split ratio (Table 1). Do not break the cell clumps to a smaller size, because the smaller clumps do not attach well to the surface. Note: We recommend a split ratio of 1:2 for the first 3 passages after the iPSCs have been passaged directly from the iPSC MEF Culture Medium to KSR-FF medium. Normally, a split ratio between 1:3 and 1:5 is appropriate, but passaging at 1:2 ensures the higher density of cells needed when adapting into a feeder-free culture.

11. Prior to plating the iPSCs on Geltrex coated dishes, aspirate residual Geltrex solution from the pre-coated dish, and slowly add an appropriate amount of cell suspension to each culture dish. Note: do not rinse dishes prior to plating.

12. Move the culture dish back and forth and side to side several times to disperse the cells across the surface of the dish. Gently place the culture dish in a $37^{\circ} \mathrm{C}$ incubator with a humidified atmosphere of 4 to $6 \% \mathrm{CO}_{2}$ in air. Replace the spent medium with $\mathrm{KSR}-\mathrm{FF}$ every day.

\section{Passaging human iPS cells using KSR-FF}

13. Observe the human iPSCs growing in complete KSR-FF under the microscope to confirm that the cells are $70-80 \%$ confluent and ready to be subcultured. Refer to Figure 1.

Note: If colonies become too dense or too large, increased differentiation occurs.

14. Cut out and remove any differentiated iPSC colonies prior to passaging the culture.

15. Pre-warm the required volume of Dispase in a $37^{\circ} \mathrm{C}$ water bath. Refer to Table 1 below for details on the volumes required.

16. Pre-equilibrate the required volume of KSR-FF in a $37^{\circ} \mathrm{C}$ water bath for $15 \mathrm{~min}$. Refer to Table 1 below for details on the volumes required.

17. Aspirate the spent medium from the culture vessel using a pipette, and rinse the cells twice with D-PBS.

18. Gently add pre-warmed Dispase solution to the culture vessel (e.g., $1 \mathrm{~mL}$ of Dispase solution per 60-mm culture dish). Swirl the culture vessel to coat the entire cell surface.

19. Incubate the culture vessel at $37^{\circ} \mathrm{C}$ for 3 minutes.

20. Remove the vessel from the incubator, aspirate the Dispase solution, and gently wash the cells with D-PBS.

21. Gently scrape the cells off the surface of the culture dish using a cell scraper, and transfer the cells to a sterile $15 \mathrm{~mL}$ centrifuge tube.

22. Rinse the culture dish twice with KSR-FF, gently "spraying off" any cells that have not detached. Pool the rinse medium with the cells in the $15 \mathrm{~mL}$ tube.

23. Centrifuge the tube at $200 \mathrm{xg}$ for 5 minutes at room temperature to pellet the cells. 
24. Carefully aspirate the supernatant without disturbing the cell pellet and discard it.

25. Gently flick the tube to fully dislodge the cell pellet from the tube bottom.

26. Gently resuspend the cells in pre-equilibrated KSR-FF using a $5 \mathrm{~mL}$ serological pipette. Do not triturate. Note: it is critical at the step to gently resuspend the cells without using force to avoid damage.

27. Transfer the cells to a fresh $60-\mathrm{mm}$ Geltrex-coated dish at the desired split ratio and move the culture dish back and forth and side to side several times to disperse the cells across its surface.

28. Place the culture dish in a $37^{\circ} \mathrm{C}$ incubator with a humidified atmosphere of 4 to $6 \% \mathrm{CO}_{2}$ in air.

29. The next day, gently replace the spent medium with KSR-FF to remove cell debris. Replace the spent medium everyday thereafter. Observe the iPS cells daily and passage them as needed (approximately every $4-5$ days). Passaging is recommended when the cells reach $70-80 \%$ confluence. For iPS cell cryopreservation and thawing, refer to our protocol titled "Cryopreserving and Recovering of Human iPS Cells using Complete KnockOut Serum Replacement Feeder-Free Medium".

\section{Expected Results}

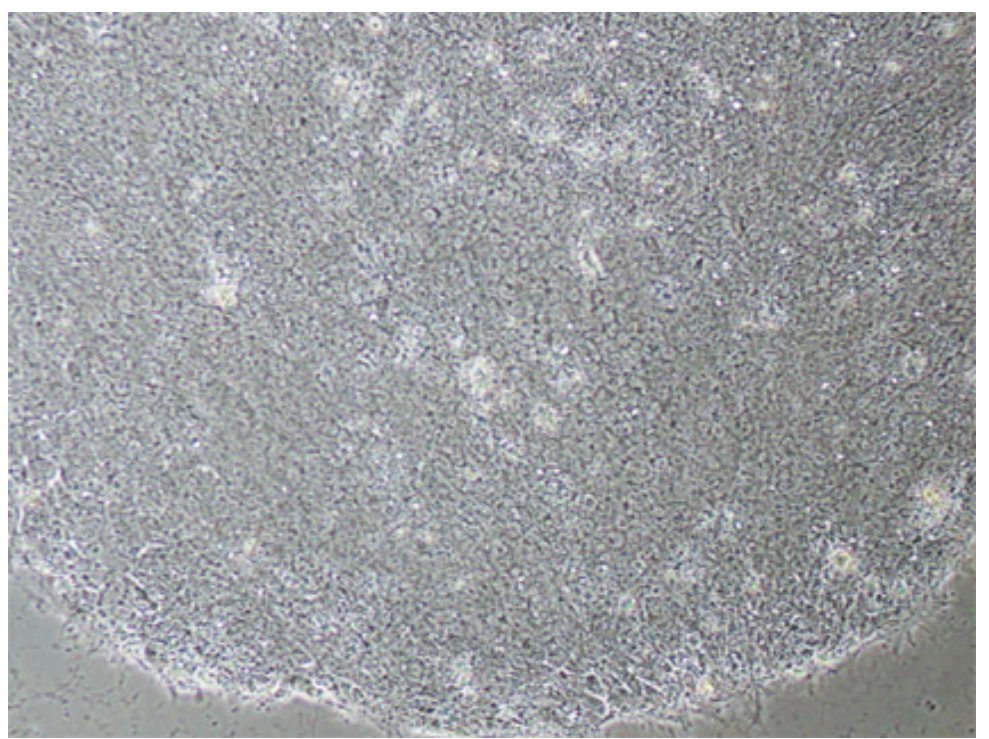

Figure 1. The phase contrast image below shows iPSCs grown on Geltrex-coated culture dishes using complete KnockOut Serum Replacement Feeder-Free medium. The iPSCs exhibit morphology similar to hESCs, characterized by large nuclei and scant cytoplasm. (40x magnification)

\begin{tabular}{|l|l|l|l|}
\hline Component & $\mathbf{3 5 m m}$ Dish & $\mathbf{6 0 m m}$ Dish & $\mathbf{1 0 0 m m ~ D i s h ~}$ \\
\hline Complete KnockOut SR medium & $2 \mathrm{~mL}$ & $4 \mathrm{~mL}$ & $10 \mathrm{~mL}$ \\
\hline Geltrex Solution & $1 \mathrm{~mL}$ & $1.5 \mathrm{~mL}$ & $4-5 \mathrm{~mL}$ \\
\hline Dispase & $0.5 \mathrm{~mL}$ & $1 \mathrm{~mL}$ & $3-4 \mathrm{~mL}$ \\
\hline D-PBS for rinsing & $2 \mathrm{~mL}$ & $4 \mathrm{~mL}$ & $10 \mathrm{~mL}$ \\
\hline
\end{tabular}

Table 1. Recommended Volumes

Please click here to see the appendix.

\section{Disclosures}

The authors of this article are employed by Life Technologies that produces reagents and instruments used in this article.

\section{References}

1. Takahashi, K. et al. Induction of pluripotent stem cells from mouse embryonic and adult fibroblast cultures by defined factors. Cell 126 : 663-676 (2006).

2. Takahashi, K. et al. Induction of pluripotent stem cells from adult human fibroblasts by defined factors. Cell 131:861-872 (2007).

3. Yu, J. et al. Induced pluripotent stem cell lines derived from human somatic cells. Science $318: 1917-1920$ (2007).

4. Maherali, N. et al. Guidelines and techniques for the generation of induced pluripotent stem cells. Cell Stem Cell $3: 595-605$ (2008).

5. $\mathrm{Li}, \mathrm{W}$. et al. Generation of rat and human induced pluripotent stem cells by combining genetic reprogramming and chemical inhibitors. Cell Stem Cell $4: 16-19$ (2009).

6. Liao, J. et al. Generation of induced pluripotent stem cell lines from adult rat cells. Cell Stem Cell $4: 11-15$ (2009).

7. Dimos, J.T. et al. Induced pluripotent stem cells generated from patients with ALS can be differentiated into motor neurons. Science 321 : 1218-1221 (2008). 
8. Aasen, T. et al. Efficient and rapid generation of induced pluripotent stem cells from human keratinocytes. Nat Biotechnli 26 : $1276-1284$ (2008).

9. Park, I.H. et al. Generation of human-induced pluripotent stem cells. Nat Protoc 3 : 1180-1186 (2008). 